\title{
POÉTICAS DO CONHECIMENTO: REPRESENTAÇÕES DOS SABERES AMAZÔNICOS EM NARRATIVAS CONTEMPORÂNEAS
}

\author{
POETICS OF KNOWLEDGE: REPRESENTATIONS OF AMAZONIAN \\ KNOWLEDGE IN CONTEMPORARY NARRATIVES
}

Claudete Daflon ${ }^{1}$

\begin{abstract}
RESUMO: Propõe-se, a partir da análise do filme colombiano El abrazo de la serpiente (2015) de Ciro Guerra e do livro A queda do céu (2016) do xamã yanomami Davi Kopenawa, discutir como narrativas contemporâneas têm representado a questão da validade e relevância do conhecimento produzido pelos povos originários da Amazônia. A questão em pauta é, portanto, como nessas narrativas são realizados deslocamentos epistemológicos e políticos que problematizam a centralidade historicamente conferida à perspectiva dos exploradores que, enquanto representantes do Ocidente europeu, desempenharam papel de destaque na construção de um imaginário sobre a região, favorecendo a consolidação de estereótipos e o consequente apagamentos de múltiplas e importantes contribuições dos povos locais. Entende-se, dessa forma, que essas narrativas são estratégicas na medida em que, por meio de procedimentos e formulações próprios, afirmam a legitimidade e a autoridade dos povos indígenas como produtores de conhecimento, bem como ressaltam os seus desdobramentos socioculturais, econômicos e políticos.
\end{abstract}

Palavras-chave: Amazônia; descolonização; conhecimento; literatura indígena; cinema latino-americano.

Resumen: Proponemos, desde el análisis de la película colombiana El abrazo de la serpiente (2015) de Ciro Guerra y el libro A queda do céu (2016) del xamã yanomami Davi Kopenawa, discutir cómo narrativas contemporáneas han representado el tema de la validad y relevancia del conocimiento que los pueblos originarios de Amazonia han producido. El tema es, por tanto, cómo en esas narrativas se realizan desplazamientos epistemológicos y políticos que problematizan la centralidad históricamente otorgada a el punto de vista de los exploradores los cuales, mientras representantes de Occidente europeo, desempeñaran rol destacado en la construcción de un imaginario sobre la región, favoreciendo la consolidación de estereotipos y las consecuentes supresiones de múltiples e importantes contribuciones de los pueblos locales. Entendemos así que esas narrativas son estratégicas puesto que, por medio de procedimientos y formulaciones propios, señalan la legitimidad y la autoridad de los pueblos indígenas como productores de conocimiento, así como destacan sus despliegues socioculturales, económicos y políticos.

Palabras-clave: Amazonia; descolonización; conocimiento; literatura indígena; cine latinoamericano.

\footnotetext{
${ }^{1}$ Universidade Federal Fluminense - UFF, Programa de Pós-Graduação em Estudos de Literatura, Departamento de Línguas Vernáculas, Niterói, Rio de Janeiro, Brasil; https://orcid.org/0000-0002-0392-8811 ; claudetedaflon@id.uff.br
}

Rev. Bras. Lit. Comp. Niterói, v. 22, n. 39, pp. 14-25, jan. /abr. 2020 https://doi.org/10.1590/2596-304X20202239cd 
Em sua contribuição para o que designou como "epistemologias do sul", o sociólogo português Boaventura de Sousa Santos propôs, em capítulo de sua autoria que integra publicação de 2010 organizada com Maria Paula Meneses, o estabelecimento de uma ecologia de saberes que implicaria, sobretudo, a superação do que o pesquisador chamou de "pensamento abissal". A investigação em torno da produção de conhecimento significava, nesse contexto, admitir a sua relevância política e, portanto, considerar que um processo efetivo de libertação dos processos de dominação exige uma emancipação epistemológica.

Nessa direção, Santos em seu livro mais recente - $O$ fim do império cognitivo: as afirmações das epistemologias do Sul (2019) - desenvolve uma sistematização que recupera discussões anteriores e avança em relação a elas. Daí realizar o mapeamento das diferenças entre as lutas inerentes ao mundo metropolitano e aquelas do mundo colonial a partir do que indica como instrumentos interrelacionados: "a sociologia das ausências e a sociologia das emergências; a ecologia de saberes e a tradução intercultural; a artesania das práticas" (Santos, 2019, p. 41). Por esse viés, Boaventura de Sousa congrega diferentes fatores, o que lhe permite atribuir dimensão geopolítica à questão do conhecimento sem excluir aspectos culturais. Diante disso, lutas do mundo metropolitano pautadas na emancipação social, ao partirem da identificação estabelecida de um "nós" humano, seriam não abissais, em contraste com as que, originadas em um "eles" não totalmente humanos, se dirigem ao fim da regulação colonial e se caracterizam, por conseguinte, como abissais. O que está em jogo na reflexão do sociólogo, de fato, são formas particulares de exclusão e as ações que demandam. Essa perspectiva é importante na medida em que se compreenda que a definição de particularidades representa um processo de sistematização que não deve fundamentar hierarquias, o que seria bastante problemático, tendo em vista que se está apostando na pluralidade e não em práticas únicas. Se é necessário enfrentar a exploração e a exclusão, em suas diversas feições, por outro lado, ao se tratar como homogêneos ou universais os processos de dominação, busca-se universalizar formas de combate e luta, o que, na conjuntura do sul global em especial, resulta um obstáculo importante para a superação da violência.

Ao contrário da luta de emancipação social no lado metropolitano da linha abissal, a luta pela libertação não visa a uma forma melhor e mais inclusiva de regulação colonial. Visa sim a sua eliminação. A prioridade epistemológica dada pelas epistemologias do Sul às exclusões abissais e às lutas contra elas deve-se ao fato de o epistemicídio causado pelas ciências modernas eurocêntricas ter sido muitíssimo mais devastador no outro lado da linha abissal, com a conversão da apropriação e da violência coloniais na forma colonial de regulação social. (Santos, 2019, p.44)

O silenciamento de outras formas de saber, em toda violência que supõe, exige um esforço de reflexão e produção teórico-crítica capaz de acionar questões, paradigmas e concepções de mundo que superem os limites impostos pelo conhecimento ocidental. Trata-se de deslocar-se da condição de objeto à de sujeito que, dono da enunciação, se situa como aquele que formula sobre o mundo.

Se considerarmos junto com Ailton Krenak (2019) que contar histórias é uma forma de opor-se aos processos de destruição do planeta, podemos, de igual maneira, compreender que tal capacidade de oposição subjacente ao narrar resulta de seu caráter epistêmico. Ou seja, enquanto realização da linguagem, em suas diferentes modalidades, as narrativas são também um modo de conhecer. Logo, contar é pensamento-ação que em sua materialidade, escrita, oral ou audiovisual, desenvolve diferentes modos de dizer-saber, o que expõe a diversidade de vozes e formatos e, por conseguinte, de saberes.

Rev. Bras. Lit. Comp. Niterói, v. 22, n. 39, pp. 14-25, jan. /abr. 2020 
Se, diante dos processos de destruição em franco andamento no mundo, o ativista e intelectual do povo Krenak expõe a força que possuem as narrativas, vale voltar uma vez mais às reflexões de Boaventura de Sousa Santos, pois, no diagrama conceitual que o sociólogo propõe em O fim do Império Cognitivo, participam os conceitos de sociologia das ausências e sociologia das emergências. Essas formas de sociologia são apresentadas como cruciais na afirmação das epistemologias do Sul, pois a primeira, ao identificar como é produzida a invisibilidade, termina por suscitar uma crítica ao conhecimento científico social e, desse modo, traz à tona saberes muitas vezes desconsiderados; enquanto a outra compreende a valorização dos sujeitos e conhecimentos antes invisibilizados. Acrescenta, então, o pesquisador definições-chave na formação dessa constelação conceitual: ecologia de saberes e tradução intercultural. É articuladamente que uma e outra favorecem uma inteligibilidade ampliada:

Na medida em que permite a articulação de diferentes movimentos sociais e de diferentes lutas, a tradução intercultural contribui para transformar a diversidade epistemológica e cultural do mundo num fator favorável e capacitador, promovendo a articulação entre lutas contra o capitalismo, o colonialismo e o patriarcado. (Santos, 2019, p. 59)

A diversidade, apresentada como aspecto fundamental, é afirmada na partilha proposta pela tradução intercultural e que subentende práticas engendradas num fazer artesanal, ainda segundo o estudioso português. Como isso se relaciona, porém, não apenas àquilo que Krenak diz em suas reflexões sobre destruição e dominação, mas também ao modo como diz?

Se a tradução intercultural tem um caráter coletivo e sua prática se dá muitas vezes "em reuniões ou sessões de atividades militante, de capacitação, de formação, de educação popular, levado a cabo através das intervenções dos participantes, sem protagonismos especiais" ou ainda "Na grande maioria dos casos o trabalho de tradução intercultural é desempenhado em grupo, anônima e informalmente em interações dominadas pela oralidade" (Santos, 2019, p. 60), há, contudo, a possibilidade de realizar-se ainda de outras maneiras: e é isso que Boaventura dos Santos busca contemplar ao afirmar que a tradução intercultural pode ser difusa ou didática de modo que a primeira ocorre "informalmente como uma dimensão do trabalho cognitivo coletivo. Caracteriza-se pela fluidez, pelo anonimato e pela oralidade" enquanto a segunda sucede "em processos que combinam, por um lado, o individual e o coletivo e, por outro, o oral e o escrito", ou seja, "a oralidade, que domina a prática da organização e da luta política, é complementada pela reflexão escrita e publicada" (Santos, 2019, p. 60-61).

Diante disso, seria possível dizer que obras como o livro de Krenak seriam uma forma de tradução intercultural didática, embora a designação possa sugerir uma instrumentalização da linguagem que soa incômoda, especialmente se considerarmos que esse didático pode ser indevidamente confundido com didatismo. Quando, todavia, se postula que esse processo de tradução se realiza pela e na linguagem e que pode ganhar expressões não restritas ao verbal, mostra-se plausível a aproximação àquilo que o poeta e ensaísta caribenho Édouard Glissant (2005) defende ao declarar, em sua poética da diversidade, que nenhuma língua deve morrer: a pluralidade cultural é também linguística.

Nesse contexto, propõe-se também imaginar o significado que pode assumir a produção audiovisual enquanto narrativa e linguagem. Em outras palavras, como considerar a contribuição cinematográfica na elaboração de ausências e emergências, especialmente quando se tem, de um lado, desenvolvimento de projetos de produção audiovisual de autoria indígena e, do outro, produção documental e ficcional assinada por diferentes cineastas. Essa questão ainda mais se complexifica quando se trata de obras que se debruçam sobre e/ou se originam

Rev. Bras. Lit. Comp. Niterói, v. 22, n. 39, pp. 14-25, jan. /abr. 2020 
da Amazônia, em especial ao deslocarem a região de sua representação habitual como objeto de conhecimento (e exploração) para a situação de lugar de produção de conhecimento.

\section{A força poético-política dos saberes amazônicos}

A questão do imaginário e da potência política das representações construídas em torno da Amazônia move a reflexão de Ana Pizarro em seu livro Amazônia: as vozes do rio (2012). A importância do discurso nesse processo é explorada pela pesquisadora que aponta como mitos produzidos sobre a região ocultam a diversidade que lhe caracteriza ao reduzi-la a noções como "território verde com populações indígenas", "paraíso" e "pulmão do mundo" (Pizarro, 2012, p. 29). Ao enfatizar sua radical heterogeneidade, a autora problematiza de igual maneira a forma e origem das construções discursivas sobre a região, ou seja, trata-se de encarar que:

A Amazônia é uma região cujo traço mais geral é o de ter sido construída por um pensamento externo a ela. Ela tem sido pensada, em nível internacional, através de imagens transmitidas por um ideário ocidental, europeu, sobre o que eles entendem ser sua natureza, ou, em outras palavras, sobre o lugar que a Amazônia ocupou na sua experiência, imagem que foi ratificada em diversos textos: crônicas, relatos de viajantes, relatórios de cientistas, informes de missionários. (Pizarro, 2012, p. 31).

Daí a premência de "escutar vozes distintas", isto é, situar em primeiro plano a pluralidade de vozes e retirar do ponto de vista moderno-ocidental sua pretensa univocidade. Todavia, a reflexão da pesquisadora agrega ainda outros aspectos, especialmente quando se trata das diferentes populações que vivem na região, ao afirmar que constitui um dos objetivos de se trabalho "Colocar em evidência os discursos orais e escritos surgidos da Amazônia" e ainda: "sejam eles de natureza estética ou, relativizando essa noção, tenham dimensão cultural" (Pizarro, 2012, p. 29). A dimensão inclusiva apontada pela autora está no fato de que busca abranger narrativas filiadas tanto a paradigmas literários ocidentais e, portanto, na esfera da escrita quanto à oralidade, bem como as que compreendem "discursos descritivos, sobre o trabalho ou a vida cotidiana, de discursos de valor comunicativo em que somente alguns possuem, ou não possuem diretamente, elementos estéticos" (Pizarro, 2012, p. 30).

Logo, diante do poder do discurso e de uma concepção da Amazônia que não pode ser dissociada de construções discursivas históricas, Pizarro propõe, precisamente, dar espaço a outras vozes, assinalando não somente sua multiplicidade, mas expondo sua importância. Esse movimento exige a análise e estudo de diferentes obras, o que inclui autores tradicionalmente estudados como os viajantes europeus, a exemplo de Théodore de Bry, e escritores consagrados pela historiografia de países como o Brasil, caso de Euclides da Cunha, assim como outros mais recentes como Milton Hatoum, sem que, todavia, isso represente limitar-se ao campo já legitimado dos intelectuais. Em outras palavras, não se trata de negar a importância da produção que tem se notabilizado na construção de um imaginário sobre a Amazônia; no entanto, não é possível reduzir a região e sua produção cultural a esse recorte. Em linhas gerais, a fim de compor o seu corpus, a pesquisadora aciona obras e autores cujas trajetórias estão associadas à região, buscando, porém, constituir como base de sua reflexão a superação de restrições vigentes, a partir das quais se prioriza a tradição literária em detrimento das vozes dos povos indígenas, quilombolas e ribeirinhos. Por conseguinte, Pizarro, sem desconsiderar referências canônicas, volta-se à oralidade para afirmar sua importância e significado muitas vezes recalcados pelo modelo da racionalidade vinculada à expressão escrita.

Rev. Bras. Lit. Comp. Niterói, v. 22, n. 39, pp. 14-25, jan. /abr. 2020 
Em síntese, os apontamentos de Ana Pizarro indicam um imaginário formado por uma pluralidade discursiva que significa diferentes modos de narrar, expressões e linguagens. Se contar histórias, de fato, compreende formas de conhecer, também nesse sentido está indicado o papel da oralidade enquanto modalidade de conhecimento. Assim, em relação à expressão oral, vale dizer, segundo propõe o antropólogo Pedro Cesarino (2018), como "as artes verbais ameríndias foram fundamentais para disparar o processo de tradução propriamente conceitual que a etnologia de então terminou por produzir" e continua "Se isso é verdadeiro, deve ser porque as artes verbais ameríndias possuem determinadas características capazes de perturbar o nosso conjunto de referências" (p. 227). Casarino defende, portanto, que as artes verbais ameríndias representam uma contribuição conceitual relevante.

Por esse viés, a partir dos parâmetros aqui estabelecidos e que orientam a reflexão que ora se desenvolve, cabe incorporar a contribuição de Boaventura de Sousa Santos, em especial no que diz respeito à premissa de que a descolonização pressupõe descolonizar o conhecimento. Afinal, a superação de modelos de dominação ainda vigentes não pode acontecer sem que haja uma renovação epistêmica e uma mudança cognitiva. Tal processo, contudo, passa pela afirmação da diversidade (algo pretendido numa ecologia de saberes) apenas possível por processos de tradução intercultural.

\section{Duas narrativas}

Entende-se, à maneira do que diz Krenak, que experiências narrativas contemporâneas, em modalidades como a fílmica ou a verbal, representam formas de conhecimento. O que dizer, afinal, das histórias que situam representantes de povos indígenas como origem de saberes válidos e urgentes? E que nos propõem um deslocamento de ponto de vista que desestabiliza estereótipos? Aqui, encontram-se artistas e povos originários.

Casarino (2018) já observara sobre A queda do céu: palavras de um xamã yanomami que se trata de uma "obra singular" enquanto "vislumbre da performance oral, reiterativa e paratática na versão final escrita": "É que La chute du ciel leva às últimas consequências um dos traços mais significativos de algumas das produções acima destacadas: o seu caráter colaborativo, a sua autoria compartilhada" (p. 223). O tom elogioso do antropólogo justificase. O livro publicado originalmente em língua francesa em 2010 e editado no Brasil em 2015 é resultado da pareceria entre o xamã yanomami David Kopenawa e o etnólogo francês Bruce Albert. É este que, no prólogo, caracteriza a publicação como "relato de vida, autoetnografia e manifesto cosmopolítico", convite "a uma viagem pela história e pelo pensamento de um xamã yanomami” (Albert, 2015, p. 43).

A singularidade da obra, na visão de Pedro Cesarino, estaria no fato de que. diferentemente da maior parte das experiências de tradução do pensamento, língua e cultura dos povos originários, em $A$ queda do céu, o autor indígena teve participação efetiva na criação do texto escrito final: "A torção do texto francês não será, aí, apenas derivada da inventividade do tradutor não indígena (como no meu caso), mas de uma influência mais direta da modulação da palavra pelo narrador original na versão escrita" (Casarino, 2018, p.224). Essa percepção vai ao encontro da avaliação que o próprio Albert faz da experiência que compartilhou com Kopenawa:

Ele [Kopenawa] se expressa por intermédio de uma imbricação complexa de gêneros: mitos e narrativas de sonho, visões e profecias xamânicas, falas reportadas e exortações políticas, autoetnografia e antropologia simétrica. Além disso, este livro nasceu de um projeto de colaboração situado na interseção, imprevisível e frágil, de dois universos

Rev. Bras. Lit. Comp. Niterói, v. 22, n. 39, pp. 14-25, jan. /abr. 2020

https://doi.org/10.1590/2596-304X20202239cd 
culturais. Sua produção, oral e escrita, foi portanto constantemente atravessada pelas visadas discursivas cruzadas de seus autores, um xamã yanomami versado no mundo dos brancos e um etnógrafo com longa familiaridade com o de seus anfitriões. (Albert, 2015, p. 50-51)

Em A queda do céu, parece estar em jogo a possiblidade de lançar mão da pele da escrita, sem reduzir-se a ela, sem processos de miscigenação que sejam apagamentos. Talvez essa experiência esteja, de fato, mais próxima da crioulização imaginada por Glissant: "A crioulização exige que os elementos heterogêneos colocados em relação "se intervalorizem", ou seja, que não haja degradação ou diminuição do ser nesse contato e nessa mistura, seja internamente, isto é, de dentro para fora, seja externamente, de fora para dentro" $(2005$, p. 20). O ensaísta acrescenta ainda que potencializa a crioulização e a diferencia fortemente de processos de miscigenação: ou seja, não se trata de combinações previstas ou que operem apagamentos mútuos, mas de encontros que resultem em relações e resultados muitas vezes inimagináveis. Enfatiza, então, a violência do choque e das imposições que geraram o crioulo para, por fim, explicitar que esses processos estão na base da ideia de crioulização que não pode, contudo, ser restrita à língua crioula. A partir de uma perspectiva que nomeia rizomática em contraposição a concepções de identidade fundadas em raízes verticais e únicas, o escritor antilhano afirma:

A relação é intensa entre a necessidade e a realidade incontornáveis da crioulização e a necessidade e realidade incontornáveis do lugar, isto é, do lugar de onde se emite a fala humana. Não emitimos palavras ao vento, soltas no ar. O lugar de onde emitimos a fala, de onde emitimos o texto, de onde emitimos a voz, de onde emitimos o grito, esse lugar é imenso. (Glissant, 2005, p.32)

A crioulização proposta por Glissant, por conseguinte, supõe não o apagamento dos lugares e contextos de enunciação, mas precisamente uma situação de poliglotismo no lugar do monoglotismo associado a pontos de vista como da modernidade ocidental enquanto universalidade imposta ao mundo num processo permanente de purificação crítica que não cansa de produzir híbridos que busca ansiosamente recalcar, para fazer referência à reflexão do sociólogo francês Bruno Latour (1994).

Logo, merece destaque a oralidade que atravessa o livro, visto que a escrita não representa ali o seu apagamento ou seu recalque. Fazer ele mesmo exercício da escrita tão cara aos brancos é algo que o xamã não se propõe, uma vez que seu conhecimento não pode ser isolado dos modelos de memória, percepção e comunicação que a língua yanomami em sua realidade oral constitui. Não é por acaso que David Kopenawa costuma iniciar suas palestras falando em sua língua por alguns minutos: se de um lado essa atitude acentua que a materialidade linguística não pode ser separada dos saberes, por outro, deixa bastante clara a relação desigual que se estabelece quando povos indígenas se veem obrigados a aprender português enquanto brasileiros desconhecem as diversas línguas faladas dentro das fronteiras do seu país. Sem dúvida, a radicalidade desse desconhecimento linguístico-cultural é atestada pelo fato de que sequer se reconhece a existência dessas línguas, ocultas sob a fachada do monolinguismo oficial.

Contudo, a urgência em rever modelos extrativistas de comportamento ecoa na necessidade declarada do xamã, ou ainda como afirma Bruce Albert: "David Kopenawa quis, desde o início de nossa colaboração, que seu testemunho atingisse a maior audiência possível"

Rev. Bras. Lit. Comp. Niterói, v. 22, n. 39, pp. 14-25, jan. /abr. 2020

https://doi.org/10.1590/2596-304X20202239cd 
(2015, p. 43). Algo ratificado em "Palavras dadas", seção do livro que corresponde à transcrição de entrevista cedida pelo xamã a Terence Turner (representante de comissão da American Anthropological Association que em 1991 investigou a situação dos Yanomami no Brasil):

Quero fazê-los escutar a voz dos xapiri, que ali brincam sem parar, dançando sobre seus espelhos resplandecentes. Quem sabe assim eles queiram defendê-la conosco? Quero também que os filhos e filhas deles entendam nossas palavras e fiquem amigos dos nossos, para que não cresçam na ignorância. Porque se a floresta for completamente devastada, nunca mais vai nascer outras. Descendo desses habitantes da terra das nascentes dos rios, filhos e genros de Omama. São as palavras dele, e as do xapiri, surgidas no tempo do sonho, que desejo oferecer aqui aos brancos. (Kopenawa; Turner, p. 65, 2015).

O posicionamento de Kopenawa na entrevista atinge frontalmente o estereótipo do indígena infantilizado ou bestializado a que o homem branco (o emprego do masculino aqui é premente), pai e algoz, oferece conhecimento e, portanto, a oportunidade de evolução em direção a uma humanidade equivalente à civilização. Na organização hierárquica dessa relação cuja imagem se difundiu a ponto de permitir que o atual presidente do Brasil, Jair Bolsonaro, a recupere em declaração proferida em 2020: "Cada vez mais, o índio é um ser humano igual a nós" 2 . O desmonte dessa perspectiva está assinalada de início na atitude do xamã: são os homens brancos que precisam de uma ação pedagógica que lhes auxilie a entender, pois eles são os ignorantes. Diante da velocidade com que vêm sendo destruídos seres e biomas, urge uma revisão da lógica extrativista que sustenta a destruição sistematizada, o que, por sua vez, torna estratégica uma pedagogia como a que propõe Kopenawa e busca na escrita poder de difusão e alcance entre brancos, público-alvo privilegiado.

De fato, em A queda do céu, o endosso da oralidade é a afirmação de uma qualidade de conhecimento que o xamã se dispõe a difundir sob a exigência de que não se fira o próprio sentido desse saber: "Eu não aprendi a pensar as coisas da floresta fixando os olhos em peles de papel. Vi-as de verdade, bebendo o sopro de vida de meus antigos com o pó de yãkoana que me deram" e "Omama não nos deu nenhum livro mostrando os desenhos das palavras e Teosi, como os dos brancos. Fixou suas palavras dentro de nós. Mas, para que os brancos as possam escutar, é preciso que sejam desenhadas como as suas." (Kopenawa; Albert, 2015, p. 76-77).

Diante da incapacidade de sair do seu modelo, de sua língua, de suas formas de pensamento, os brancos permanecem surdos e incapazes de compreender o que povos como os Yanomami teriam a dizer. Torna-se premente, portanto, estabelecer uma situação elementar de comunicação, viável apenas na medida em que se reconhece o outro como uma existência à maneira do nós. A divisão entre um nós e eles que caracteriza o pensamento abissal está assentada em processos históricos e filosóficos de diferenciação que sustentam oposições como corpo/alma e natureza/cultura. A profundidade das diferenças impossibilita uma atitude efetivamente comunicativa.

A vinculação ao frame da transmissão oral a um ouvinte habilitado a assumir a função de escriba remete, sem dúvida, à reflexão de Walter Benjamim em seu texto bastante conhecido sobre a arte de narrar. $\mathrm{O}$ narrador, na perspectiva benjaminiana, estaria associado à transmissão coletiva de experiências e conhecimentos úteis e teria como arquétipos o viajante e o artífice, que forjariam as condições necessárias à transferência oral de saber. Marco Polo encarna esse narrador e, enquanto tal, exercita sua narrativa na oralidade. Assim, o mercador veneziano,

\footnotetext{
${ }^{2}$ https://g1.globo.com/politica/noticia/2020/01/24/cada-vez-mais-o-indio-e-um-ser-humano-igual-a-nos-dizbolsonaro-em-transmissao-nas-redes-sociais.ghtml
}

Rev. Bras. Lit. Comp. Niterói, v. 22, n. 39, pp. 14-25, jan. /abr. 2020 https://doi.org/10.1590/2596-304X20202239cd 
preso em Gênova após seu retorno do oriente, narra a um companheiro de cela, identificado como Rusticiano de Pisa, suas histórias. Este assumirá o papel de escriba e declarará sobre o teor do relato: “...assim as descreverá nosso livro e vo-las explicará, clara e ordenadamente, como as conta Misser Marco Polo, sábio e nobre cidadão de Veneza, tal como as viram seus olhos mortais" (Polo, 1999, p. 45).

No contexto desse formato de transmissão oral destinada a um escriba, a cena original traz a força do testemunho, recurso retórico capaz de conferir veracidade ao maravilhoso. $\mathrm{Ou}$ seja, reduzida a ponto de partida e atestado de verdade, a oralidade parece passar o bastão para a escrita, num procedimento que se compreende como bem distinto do que se opera no consórcio entre o xamã David Kopenawa e o etnólogo Bruce Albert.

Dessa maneira, ainda que o contexto em que se origina A queda do céu remeta à moldura da transmissão oral-escrita da narrativa, assume outra feição, já que, ao apresentar suas palavras registradas em pele de papel e, portanto, sob o regime da lógica dos brancos, o xamã busca sobretudo a afirmação do sentido performático e presencial da oralidade. Isto é, se o livro se apresenta como meio necessário para fazer com que as palavras do sábio indígena cheguem a grupos mais amplos, ele não representa a sujeição ao paradigma estético-cognitivo da escrita. Isso porque a captura no papel do relato oral por um ouvinte atento não se reveste de univocidade graças à dimensão essencialmente cooperativa do livro. Melhor dizendo: não se trata da substituição ou transcrição do relato oral para a escrita, se trata de uma tradução intercultural que, enquanto tal, respeita as singularidades das vozes e formatos que constituem a narrativa. Trata-se, portanto, de uma dinâmica complexa em que a escrita do etnólogo francês coexiste com a oralidade do saber xamânico, em contraste com a pretensa literalidade da transcrição dotada de autoridade como, por exemplo, no relato paradigmático das aventuras de Marco Polo.

Em linhas gerais, entende-se que a complexidade relacional inscrita na proposta de $A$ queda do céu resulta de um compósito no qual a oralidade não é limitada a condição original de transmissão de conhecimento, mas é em si assumida como forma de saber cujas particularidades devem, na medida do possível, ser preservadas no contato com a escrita. Esta, por sua vez, acionada como modo de conhecer e recurso comunicativo, estará sujeita às contaminações e tensões providas pela interface com o discurso oral.

Outras questões propõe o trabalho do cineasta colombiano Ciro Guerra, conquanto aborde situações e problemáticas afins àquelas presentes em A queda do céu. Em seu longa-metragem de 2015, El abrazo de la serpiente, encontra-se novamente uma relação de transmissão de conhecimento que subverte a imagem convencionada do indígena ignorante e do branco sábio. É aqui também um xamã de povo originário da Amazônia, Karamakate, que detém a sabedoria capaz de ajudar a ver com outros olhos sujeitos fantasmagóricos, brancos perdidos em suas crenças: cientistas e exploradores representados em dois marcos temporais distintos mas que se confundem como duplos na memória do xamã. O primeiro, que manteve contato com Karamakate ainda jovem, constitui construção ficcional que evoca a tradição de naturalistas germânicos que estudaram a Amazônia - o personagem chamado Theodor von Martius nos encaminha a referências importantes com Karl Friedrich Philipp von Martius (1794-1868) e Theodor Koch-Grünberg (1872-1924). Já o segundo é estado-unidense e segue as pegadas de Theodor, na medida que dirige sua viagem a partir dos escritos deixados pelo cientista já falecido: Evan é referência clara ao etnobotânico Richard Evans Schultes (1915-2001) ao mesmo tempo em que representa o encontro do interesse científico com as ambições políticas e econômicas do mundo moderno. As menções quase diretas aos pesquisadores permitem reconstruir um fio histórico que revela diferentes gerações de cientistas e sua ação na Amazônia, assim como expõe a repercussão na região de interesses religiosos, tecnológicos e político-

Rev. Bras. Lit. Comp. Niterói, v. 22, n. 39, pp. 14-25, jan. /abr. 2020 
econômicos internacionais. A questão da exploração da borracha desempenha, nesse sentido, papel importante no filme.

Diferentemente de $A$ queda do céu, a produção audiovisual decorre do trabalho de um homem não-indígena, o cineasta, em sua visão sobre os povos amazônicos e a sociedade branca da qual ele mesmo faz parte. Nesse sentido, não haveria o encontro de uma oralidade-escrita representada na situação de cooperação entre ameríndio e antropólogo, antes haveria a proposta declarada de ficcionalização que recupera estudos antropológicos e de outros matizes que dizem respeito à história contada sobre a Amazônia. O fato, contudo, de a linguagem cinematográfica encerrar em certa dimensão o performático, seja dos atores seja das situações referidas, e por meio da conjunção imagem-voz evocar uma presença, possibilita uma experiência particular voltada para a difusão do entendimento de que seriam os brancos quem teriam que aprender. Convida-se, assim, o espectador a um deslocamento em direção ao reconhecimento da legitimidade de um conhecimento ameríndio. Ainda nesse sentido, a enunciação cabe ao indígena de maneira que não só seja refutada a condição de primitivo incapaz como também seja afirmada a sua capacidade de produção de saberes válidos. Na realidade, essa é a "virada" que se opera na trajetória da personagem do xamã em El abrazo de la serpiente, uma vez que o desenlace dado à narrativa só é possível graças à compreensão pelo protagonista de que não é, como supunha inicialmente, aos demais do seu povo que precisava ensinar a fim de evitar o crescente apagamento de costumes e a aculturação de seus pares. Mais velho, vivendo o espelhamento de uma experiência de sua juventude com o estrangeiro branco em viagem pela Amazônia, se dá conta que o caminho está em ensinar os brancos.

O filme, porém, encontra-se circunscrito às suas próprias fronteiras. Em outras palavras: não deixa de ser a produção decorrente do olhar externo sobre a realidade amazônica. Isso não significa, no entanto, que não tenha validade, apenas que deve ser considerado a partir dessa sua realidade. Quanto a isso, merece atenção a opção pela fotografia em preto e branco, algo que se entende aqui como parte de uma proposta narrativa clara. Em primeiro lugar, o filme sem cores ao mesmo tempo que evita o exotismo recorrentemente atribuído à exuberância do “inferno verde" amazônico tem função narrativa, já que a cor é particularidade da visão ampla e privilegiada (o fim de uma cegueira que lança os homens à situação de fantasmas) alcançável apenas por uma experiência sensorial inerente ao transe xamâmico. A ampliação sensorial é registrada precisamente pelo colorido das imagens. Em segundo lugar, a estética em preto e branco dialoga claramente com a tradição do filme etnográfico e remete, portanto, à própria condição de origem de um filme que, ficcional, se constrói a partir de modelos narrativos documentais associados à etnografia. Em terceiro, não se pode ignorar o significado dessa opção no contexto da produção fílmica do cineasta, visto que antes de El abrazo de la serpiente, Ciro Guerra havia realizado La sombra del caminante (2002) também em preto e branco e em $35 \mathrm{~mm}$.

Consequentemente, a estética da película atende à interseção de diferentes aspectos a partir de um roteiro que retoma a situação arquetípica da viagem, na travessia do rio-serpente que também é uma jornada interior. Os aspectos social e individual convergem na medida em que os sujeitos envolvidos também representam sociedades e culturas, enquanto o processo de transformação mútua e o aprendizado estabelecem conexões com o formato da narrativa que inclui a moldura do romance de formação e dos relatos de viagem. Por outro lado, a serpente, em sua alusão tanto a imagens do pensamento ameríndio quanto ao rio Amazonas (em que pese a centralidade que o rio muitas vezes detém em narrativas amazônicas, a exemplo do que observa Ana Pizarro), também representa possibilidades de conhecimento recalcadas e restituídas na situação apresentada pelo filme. Na verdade, a narrativa fílmica, em suas

Rev. Bras. Lit. Comp. Niterói, v. 22, n. 39, pp. 14-25, jan. /abr. 2020

https://doi.org/10.1590/2596-304X20202239cd 
duplicidades e diálogos entre ficcional e documental, problematiza formas de conhecimento em sua própria existência como linguagem.

Nesse contexto, o fluxo do rio-serpente-filme se constitui como um contar histórias que propõe conferir importância a outras formas de conceber e perceber o mundo, em especial aquelas vividas por xamãs e povos amazônicos. Por esse viés, a Amazônia de El abrazo de la serpiente é mítica e etnográfica e ficcional. É nesse regime múltiplo que a película de Ciro Guerra pode operar a construção da situação de aprendizagem que reorganiza relações hierárquicas fortemente difundidas: a narrativa cinematográfica nos abraça tal qual a serpente para nos realocar. Espectadores são situados, dessa forma, também como parte de uma viagem em que aprender significa compreender o quanto outros povos têm a ensinar e quanto precisamos desse ensinamento.

\section{Considerações finais}

A pluralidade e relevância dos significados que a serpente supõe são exploradas em livro ousado do antropólogo canadense Jeremy Narby - A serpente cósmica: o DNA e a origem do saber, cuja primeira edição em francês se deu em 1995. O encontro da proposta de Narby com as perspectivas propostas pelas duas narrativas objeto desse artigo começa pela compreensão de que o transe xamâmico ocasionado pelo uso de plantas psicoativas é forma indubitável de conhecimento sobre o mundo. Ao apontar as raízes coloniais da antropologia, Narby observa que a denominação "xamanismo" foi criada pelos antropólogos "para classificar as práticas menos compreensíveis dos "primitivos'." (2018, p.22), o que significa em última instância, como afirma, o emprego de premissas da racionalidade ocidental para compreender aquilo que não se situa na mesma moldura epistemológica. Nesse sentido, em sua experiência com os Ashaninka na Amazônia peruana, o antropólogo relata seu contato com formas de conhecimento e explicações que denotavam pertinência prática ao mesmo tempo que não se ajustavam à sua compreensão de mundo. $\mathrm{O}$ caráter revelador de experiências compartilhadas com os Ashaninka, em especial as transformações que sofre em seu modo de ver o mundo a partir de experiências de transe com o consumo de ayahuasca, leva o pesquisador a rever convicções e propor: "Em geral, cientistas se negam a aceitar que índios 'vivendo na idade da pedra' possam ter desenvolvido o que quer que seja" (Narby, 2018, p.47).

A experiência do canadense remete a outros relatos de antropólogos que mais contemporaneamente vêm submetendo à revisão a própria tradição da antropologia e etnografia; o que aparece figurado, sem dúvida, no filme de Ciro Guerra, especialmente nas relações constituídas pelas personagens dos homens brancos, seja o cientista seja o biopirata, ambos extrativistas à sua maneira, em relação ao xamã de quem necessitam para alcançar a cura e/ou conhecimento estratégico dos recursos naturais locais.

Para o desenvolvimento de sua reflexão sobre a possibilidade de que a alteração da percepção operada no transe xamânico possa gerar formas outras de produção de conhecimento, Narby lança mão da literatura produzida não só no campo da antropologia, mas também da biologia: "ver ao mesmo tempo essas duas realidades, a biologia molecular e o xamanismo, que o nosso espírito racional separa a priori, mas que, na realidade, podem formar uma única realidade!"' (2018, p77). Daí interessar-se pela imagem da serpente, haja vista sua recorrência e significância em diferentes culturas, com destaque para sua presença entre povos amazônicos. Na proposição de uma possível analogia entre o DNA como princípio vital e representações mitológicas de serpentes duplas, o autor retoma conjunto significativo de trabalhos e autores, além de assinalar diversos aspectos usuais na representação desses seres como: a sua relação com a água; a sua condição de criadora da vida; a condição de agente da metamorfose; espécie

Rev. Bras. Lit. Comp. Niterói, v. 22, n. 39, pp. 14-25, jan. /abr. 2020 
de axis mundi, noção "particularmente espalhada entre os povos indígenas da Amazônia" (Narby, 2018, p.98).

Não se pretende aqui avaliar o mérito da hipótese defendida por Jeremy Narby segundo a qual haveria uma aproximação inegável entre as representações mitológicas das serpentes duplas e a dupla hélice da estrutura do DNA proposta pelos cientistas Francis Crick e James Watson. Interessa, porém, sua contribuição tanto no que diz respeito ao estudo dos modos como a serpente comparece em narrativas e imagens de povos diversos, em especial os amazônicos, quanto no sentido de se considerarem outras possibilidades de conhecimento que escapem ao científico e a modelos autorizados no âmbito das sociedades ocidentais. Está em jogo a superação da compartimentalização do pensamento, tendo em vista suas evidentes limitações, sejam elas epistemológicas ou políticas, a favor de uma ecologia dos saberes, como propõe Boaventura de Sousa Santos, ou ainda da crioulização, como compreendida por Édouard Glissant.

Tal superação está de certa forma implicada na abordagem empregada e nas conclusões a que chega Jeremy Narby, como ao referir-se a situações como a seguir:

As cobras estão onipresentes não só nas alucinações, nos mitos e nos símbolos dos seres humanos em geral, mas também nos seus sonhos. De acordo com alguns estudos, 'os habitantes de Manhattan sonham com elas tão frequentemente quanto os zulus'. Um dos mais conhecidos sonhos desse tipo é o de August Kekulé, o químico alemão que descobriu, certa noite de 1862, cochilando em frente à lareira, a estrutura cíclica do benzeno, e viu, em estado semionírico, uma cobra que dança diante dos seus olhos fechados e mordia o próprio rabo. Segundo um comentador, 'não é preciso lembrar que essa contribuição foi fundamental para o desenvolvimento da química orgânica'. (p.118, 2018).

Por outro lado, a questão da linguagem, o uso de metáforas e o próprio narrar estão implicados em modos de conhecer não restritos à ciência moderna, daí a contribuição do livro de Narby derivar, em grande parte, do que havia assinalado Ailton Krenak a respeito do papel das narrativas:

Ao contar minha história pessoal, quis criar uma narrativa que fosse compreensível pelas diversas disciplinas e fora do meio acadêmico.

Tal decisão se inspira também nas tradições xamânicas que invariavelmente afirma que as imagens, as metáforas e as histórias são o melhor meio de se transmitir o saber. Nesse sentido, os mitos são precisamente formas de 'narrativas científicas', ou histórias versando o saber (a palavra 'ciência' vem do latim scire, saber). (Narby, 2018, p. 159).

Nesse ponto, encontram-se o filme colombiano e A queda do céu: experiências diversas entre si, fundadas, no entanto, no valor cognoscível da narrativa que, concebida como forma de conhecer, contrapõe-se a parâmetros sustentados em discursos de autoafirmação e universalidade. O silenciamento violento de experiências e conhecimentos que não correspondam a modelos de conhecimento legitimados a partir do Ocidente europeu tem um custo algo, indicado na crescente destruição de povos e seres da Amazônia. As narrativas da e sobre a região podem constituir-se, desse modo, como recusa de sua absoluta objetivação, uma vez que esta, ao negar-lhe existência e subjetividade próprias, justifica a atitude extrativista que drena vidas e saberes.

Rev. Bras. Lit. Comp. Niterói, v. 22, n. 39, pp. 14-25, jan. /abr. 2020 


\section{REFERÊNCIAS}

ALBERT, Bruce. Prólogo. In: KOPENAWA, David; ALBERT, Bruce. A queda do céu: palavras de um xamã yanomami. Trad.: Beatriz Perrone-Moisés. São Paulo: Companhia das Letras, 2015.

BENJAMIN, Walter. Obras escolhidas: Magia e técnica, arte e política. Trad. Sérgio Paulo Rouanet. São Paulo: Brasiliense, 1994.

CESARINO, Pedro. Eventos ou textos? A pessoa múltipla e o problema da tradução das artes verbais amazônicas. In: DAHER, Andrea (org.). Oral por escrito: a oralidade na ordem escrita, da retórica à literatura. Chapecó, SC: Argos; Florianópolis, SC: EDUSC, 2018. p.217-255 GLISSANT, Édouard. Introdução a uma Poética da diversidade. Trad. Enilce do Carmo Albergaria Rocha. Juiz de Fora: UFJF, 2005.

GUERRA, Ciro; TOULEMONDE, Jacques. El abrazo de la serpiente: guiones. Los cuadernos de cinema, n. 23, 2016.

KOPENAWA, David; ALBERT, Bruce. A queda do céu: palavras de um xamã yanomami. Trad.: Beatriz Perrone-Moisés. São Paulo: Companhia das Letras, 2015.

KOPENAWA, David; TURNER, Terence. Palavras dadas. In: KOPENAWA, David; ALBERT, Bruce. A queda do céu: palavras de um xamã yanomami. Trad.: Beatriz Perrone-Moisés. São Paulo: Companhia das Letras, 2015.

KRENAK, Ailton. Ideias para adiar o fim do mundo. São Paulo: Companhia das Letras, 2019. LATOUR, Bruno. Jamais fomos modernos. Trad. Carlos Irineu da Costa. Rio de Janeiro: Ed. 34, 1994.

NARBY, Jeremy. A serpente cósmica: o DNA e a origem do saber. Trad. Jorge Bastos. Rio de Janeiro: Dantes, 2018.

PIZARRO, Ana. Amazônia: as vozes do rio. Trad. Rômulo Monte Alto. Belo Horizonte: UFMG, 2012.

POLO, Marco. O livro das maravilhas. Trad. Elói Braga Jr. Porto Alegre: L\&PM, 1999.

SANTOS, Boaventura de Sousa; MENESES, Maria Paula (org.). Epistemologias do sul. São Paulo: Cortez, 2010.

. O fim do império cognitivo: afirmações das epistemologias do sul. Belo Horizonte:

Autêntica, 2019.

Claudete Daflon é professora do Programa de Pós-Graduação em Estudos de Literatura da Universidade Federal Fluminense e coautora de Agentes do contemporâneo (Niterói: EDUFF, 2016). Mais informações em http://lattes.cnpq.br/5410973802965854

Submetido em 13/11/2019

Aprovado em 18/12/2019

Rev. Bras. Lit. Comp. Niterói, v. 22, n. 39, pp. 14-25, jan. /abr. 2020 